\title{
Studi Penelusuran Kesesuaian Kurikulum Program Studi Sarjana Seni Musik Terhadap Kebutuhan Dunia Kerja
}

\author{
Ayub Prasetiyo \\ Jurusan Musik, FSP ISI Yogyakarta;+62818274677; e-mail: biru_bening@yahoo.co.id
}

\begin{abstract}
In the past thirty one years, the Music Department of ISI Yogyakarta has contributed to the development of music in Indonesia as the agent of change to build the human resources in the field of Western music. However, there has been no attempt to establish a relationship to the alumni of Music Departmentto provide contributions for the development Music Department of ISI Yogyakarta. Therefore, this research aims to search the Alumni of Music Department of ISI Yogyakarta in the period time of 2002 until 2012 in order to get the profile of the alumni and also to get the feedback on the suitability of the curriculum in Music Department to the needs of the workforce. This research uses qualitative method with descriptive statistical approach. The data collected by simple random sampling with 61 respondents from the alumni of Music Department of ISI Yogyakarta which spread all over Indonesia. The result of this research revealed that the learning process in Music Department of ISI Yogyakarta is able to provide supplies competence to compete in workforce. According to the data most of alumni of Music Department of ISI Yogyakarta are music educators. As a suggestion to meet the work forcerequirement as music educators, there should be additional skill for students (soft skills) such as organizational skills, leadership, oral communication and the experience in community empowerment.
\end{abstract}

Keywords: alumni, Music Department, workfore

\begin{abstract}
Abstrak
Telah tigapuluh satu tahun Jurusan Musik memberi kontribusi terhadap perkembangan musik di Indonesia, dengan menjadi agen perubahan bagi terciptanya sumber daya manusia di bidang musik Barat. Namun belum ada usaha untuk menjalin silaturahmi kepada para alumni guna memberikan sumbang saran bagi kemajuan Jurusan Musik. Untuk itu, penelitian ini berusaha menelusuri para alumnus Jurusan Musik dari tahun 2002 hingga 2012 guna mendapatkan bagaimana profile alumni Jurusan Musik selama ini dan mencari feedback terhadap kesesuaian kurikulum di Program Studi Seni Musik terhadap kebutuhan dunia kerja. Penelitian ini menggunakan jenis penelitian kualitatif dengan pendekatan statistik deskriptif. Perolehan sampel populasi dengan cara simple random sampling dengan responden sebanyak 61 alumni yang tersebar di seluruh Indonesia. Hasil penelitian mengungkap bahwa proses pembelajaran berdasarkan kurikulum di Jurusan Musik mampu memberikan bekal kompetensi yang sangat cukup bagi para alumni untuk berkompetisi di dunia kerja. Namun harus ada pembekalan tambahan bagi mahasiswa yang bersifat soft skill seperti kemampuan berorganisasi, kemampuan memimpin, kemampuan komunikasi lisan dan pengalaman dalam pemberdayaan masyarakat mengingat hampir sebagian besar para alumni Jurusan Musik berprofesi sebagai pendidik musik.
\end{abstract}

Kata Kunci: Alumni, Jurusan Musik, dunia kerja.

\section{Pendahuluan}

\section{Latar Belakang}

Sejak bergabung menjadi ISI Yogyakarta di tahun 1984, Program Studi S-1 seni musik telah banyak meluluskan alumni yang bekerja hampir menyebar di seluruh
Indonesia. Walaupun peneliti belum memiliki data pasti, peneliti berasumsi jika setiap tahun Jurusan Musik rata-rata meluluskan 40 mahasiswa maka bisa diketahui jumlah lulusan Jurusan Musik dari tahun 1984 hingga 2014 adalah 1.200 alumni. 
Sekali lagi data ini belum valid karena masih menjadi asumsi peneliti, mengingat penerimaan dan kelulusan mahasiswa sejak tahun 1984 hingga 2014 mengalami pasang surut.

Berdasarkan asumsi tersebut, 1.200 alumni adalah angka yang tidak sedikit bagi perguruan tinggi seni yang kurang diminati dibanding program studi di perguruan tinggi umum lainnya. Relatif banyaknya alumni sebagai produk kelulusan Program Studi S-1 Seni Musik menggelitik peneliti untuk menelusuri sejauh mana lulusan tersebut terserap dalam lapangan kerja di masyarakat, dan sebagai profesi pekerja seni khususnya pekerja musik, sejauh mana kompetensi keilmuan yang didapat selama menimba ilmu di Program Studi S-1 seni musik bermanfaat dan mampu bersaing dengan lulusan lembaga pendidikan atau perguruan tinggi seni lainnya.

Penelitian penelusuran kesesuaian kurikulum sarjana program studi seni musik terhadap kebutuhan dunia kerja sepengetahuan peneliti belum pernah dilakukan di lingkup Fakultas Seni Pertunjukan ISI Yogyakarta. Hasil penelitian yang akan dilakukan tentunya menjadi penting bagi Institut seni Indonesia Yogyakarta, khususnya Program Studi S-1 seni musik untuk mengetahui keberhasilan proses pendidikan yang telah dilakukan terhadap anak didiknya. Penelitian dilakukan untuk mengukur kinerja program studi melalui output yang dihasilkan program studi.

Penelitian ini tentunya tidak secara langsung memberikan kontribusi bagi pengembangan keilmuan bidang musik, namun dari umpan balik yang akan diperoleh nantinya, peneliti berharap akan didapatkan wacana dan dimensi pemikiran baru terhadap pengembangan kurikulum guna membentuk lulusan yang dapat memenuhi tuntutan dunia kerja dan menjadi acuan bagi pengembangan dan pelaksanaan sistem penjaminan mutu pendidikan musik.
Berdasarkan uraian latar belakang maka temuan rumusan masalahnya adalah: (1) Bagaimanakah profile lulusan program studi S-1 Seni Musik? (2) Bagaimanakah relevansi antara kurikulum dengan kebutuhan lapangan pekerjaan?

\section{Tinjauan Pustaka}

Berdasarkan referensi yang ada, peneliti mengalami kesulitan untuk mendapatkan jurnal penelitian ataupun bukubuku yang akan digunakan sebagai rujukan dalam meninjau pustaka, mengingat penelitian ini tidak berhubungan langsung dengan temuan keilmuan. Untuk itu, tinjauan pustaka disini lebih menekankan pada penjelasan etimologis atau definisi dari sumber-sumber terbatas berdasarkan judul penelitian.

Penelusuran adalah kegiatan untuk mendapatkan informasi. Informasi yang ingin diungkap dalam penelitian ini adalah tentang keberadaan alumni setelah lulus kuliah. Informasi yang akan diungkap mencakup: (1) profile lulusan, (2) masa tunggu alumni semenjak lulus hingga mendapatkan pekerjaan, (3) persentase lulusan yang sudah bekerja, (4) kepuasan alumni atas kinerja program studi, dan (5) tanggapan alumni atas relevansi keilmuan yang dipelajarinya dengan kebutuhan dunia kerja.

Menurut Schomburg (2003) tujuan utama dari Tracer Study adalah untuk mengetahui kualitas alumni atau lulusan di dunia kerja, sedangkan tujuan khususnya adalah : (1) Mengetahui profile kompetensi lulusan; (2) Mengetahui relevansi pelaksanaan kurikulum yang diterapkan di perguruan tinggi terhadap kebutuhan dunia kerja guna pengembangan kompetensi jurusan; (3) Mengevaluasi kurikulum program studi sebagai sebuah upaya pengembangan keilmuan; (4) Memberi kontribusi dalam penilaian akreditasi program studi. 
Pengertian kurikulum dalam Peraturan Menteri Pendidikan dan Kebudayaan Republik Indonesia No 49 Tahun 2014 tentang Standar Nasional Pendidikan Tinggi adalah seperangkat rencana dan pengaturan mengenai capaian pembelajaran lulusan, bahan kajian, proses, dan penilaian yang digunakan sebagai pedoman penyelenggaraan program studi.

Ross (2000: 8) menyatakan curriculum berasal dari bahasa Latin yang berarti arena balap, yang kemudian mengalami pergeseran makna menjadi bahan ajaran untuk sebuah pembelajaran. Menurutnya, bahan kajian dari kurikulum sebagai pedoman penyelenggaraan program studi seharusnya tidak bersifat formal, kaku dan sesempit gagasan tentang kurikulum nasional yang membatasi cakupannya berdasarkan konten yang ditentukan selama proses pendidikan, namun harus ada agenda kurikulum 'tersembunyi' untuk menguatkan kemampuan anak didik setelah lulus.

Buku yang di editori Luis (2011) ini membahas pendekatan yang berbeda dari pendidikan musik untuk guru dan reformasi program yang sedang berlangsung dengan mengevaluasi berbagai program pendidikan guru musik di seluruh Eropa dan Amerika Latin sebagai refleksi perubahan kondisi global, penyebabnya, dan faktor di mana pengetahuan musik dan pendidikan tersebut dibangun. Buku ini menyajikan tujuh studi kasus yang terjadi di Argentina, Brasil, Meksiko, Portugal, Spa-nyol, dan Swedia guna memahami secara umum elemen spesifik tiap program, dan cara elemenelemen ini berhubungan de-ngan sebuah perubahan besar era globalisasi dari masingmasing negara yang mengala-minya.

\section{Tujuan dan Manfaat Penelitian}

Adapun tujuan dari penelitian ini adalah: (1) Mengidentifikasi profile program studi S-1 Seni Musik, dan (2) Mengidentifikasi relevansi antara kurikulum dengan kebutuhan lapangan pekerjaan. Ada dua manfaat yang diharapkan dari penelitian ini. Pertama ialah adalah agar program studi mampu menelusuri profile lulusan yang telah bekerja sesuai dengan latar belakang pendidikan yang didapatnya dan mengevaluasi relevansi sebaran kurikulum dengan bidang pekerjaan yang ada. Manfaat kedua ialah bagi mahasiswa, agar dapat memberikan umpan balik bagi kualitas penyelenggaraan pendidikan bagi almamaternya. Selain itu diharapkan dampak lanjutan dari penelitian ini dapat terbina ikatan alumni di program studi S-1 Seni Musik.

\section{Metode Penelitian}

Kajian tracer study ini merupakan penelitian dengan pendekatan deskriptif statistik dari jenis penelitian mix method antara kualitatif dan kuantitatif yang berusaha mendeskripsikan profil lulusan dan relevansi sebaran materi kuliah Program studi S-1 Seni Musik dengan kebutuhan dunia kerja. Area penelitian diambil dari sebaran alumnus di seluruh Indonesia. Estimasi waktu penelitian dilakukan selama delapan bulan dari bulan april hingga bulan november. Penentuan populasi subjek penelitian menggunakan teknik purposive sampling yaitu hanya alumni Jurusan Musik dari tahun 2002 hingga 2012 yang bertempat tinggal dan bekerja di seluruh Indonesia.

a. Instrumen Penelitian

Menurut Sugiyono (2011; 222) dalam penelitian kualitatif yang menjadi instrumen atau alat penelitian adalah peneliti itu sendiri. Sementara dalam penelitian kuantitatif instrumen penelitiannya dapat berupa test, pedoman wawancara, pedoman observasi dan kuesioner.

b. Teknik Pengumpulan Data

Pengumpulan data akan dilakukan dengan empat tahapan yaitu, studi dokumen, observasi, kuesioner dan wawancara. 1) Studi dokumen adalah langkah awal yang 
dilakukan dalam penelitian ini. Dokumen yang dimaksud adalah pencarian data-data akademis dan riwayat mahasiswa selama menempuh pendidikan. 2) Observasi diperlukan untuk menentukan informan primer yang kira-kira mengetahui banyak informasi terkait keberadaan alumni. 3) Kuesioner dikirim melalui kiriman pos atau media elektronik (e-mail). Penggunaan kuesioner dilakukan mengingat sebaran populasi yang begitu luas. 4) Teknik pengumpulan data wawancara akan dilakukan secara acak melalui telepon berdasarkan keunikan jawaban yang diberikan responden.

c. Analisis Data

Analisis dilakukan melalui reduksi data. Reduksi data di sini bukan berarti penyederhanaan yang mengurangi kualitas data, akan tetapi sebaliknya, yakni bertujuan untuk meningkatkan data sehingga kompilasi data yang semula belum teratur dapat disusun kembali ke dalam bentuk baru.

\section{Pembahasan}

\section{Deskripsi Data}

Berdasarkan pengolahan data kuesioner yang diperoleh melalui e-mail ataupun mail post diperoleh gambaran mengenai alumni sebagai berikut:

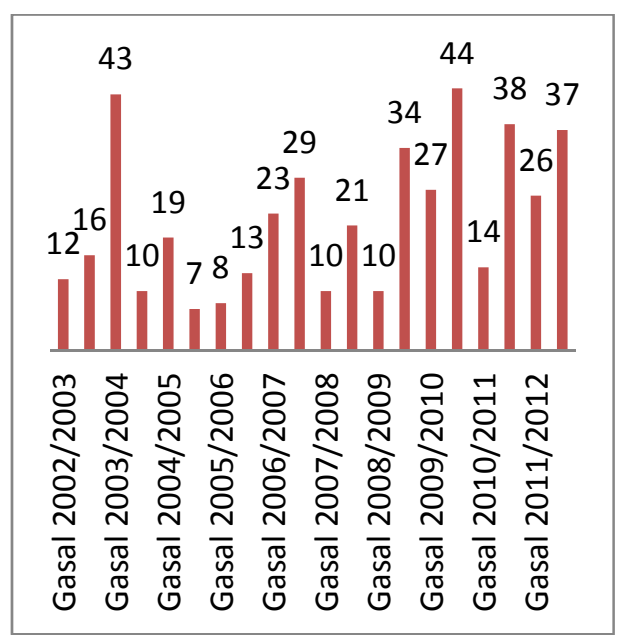

Gambar 1.

Populasi Penelitian
Dari total populasi penelitian, dalam hal ini alumni dari semester gasal 2002/2003 hingga semester genap 2011/2012 yaitu 441 alumni yang bisa dilacak alamat atau kontak personnya melalui no $\mathrm{HP}$, E-mail ataupun messanger adalah sejumlah 133 alumni. Hingga dead line waktu yang telah ditentukan, responden yang mengembalikan kuesioner sejumlah 61 responden. Meskipun demikian, hal ini masih sesuai dengan pendapat Gay dan Diehl (1992) bahwa Jika penelitiannya bersifat deskriptif, maka sampel minimumnya adalah $10 \%$ dari populasi alumni. Jika populasinya 441 maka 10\% dari 441 adalah 44 sampel. Informasi tentang keberadaan alumni yang sudah tidak valid baik alamat rumah maupun telephone yang diperoleh melalui studi dokumen (data wisuda) menjadi kendala sendiri hingga sedikit banyak mempengaruhi jumlah responden.

Dari pengembalian kuesioner yang telah diperoleh sejumlah 61 responden bisa dipilah berdasarkan minat utama adalah musik pendidikan atau musik sekolah 49, musikologi 5, komposisi 4 dan pertunjukan musik 3 yang bisa dilihat pada diagram di bawah ini:

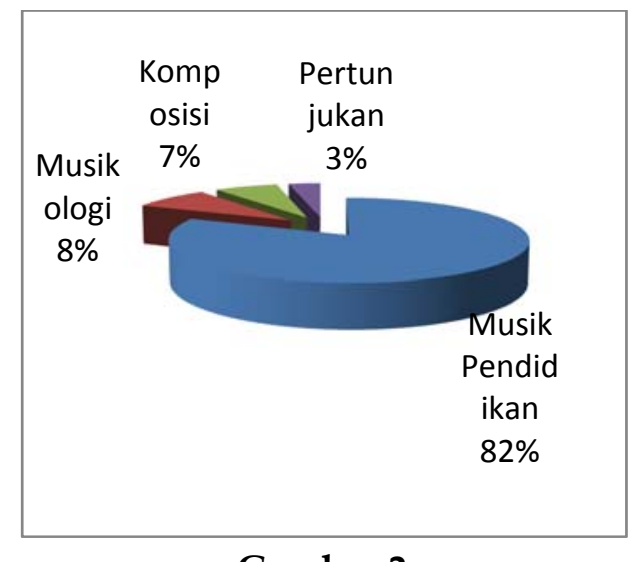

Gambar 2.

Data kuesioner berdasarkan minat utama

a. Profile Lulusan

Profile lulusan bisa dikategorikan menjadi 5 profesi yaitu profesi di luar bidang musik 6 responden, guru kursus musik 
15 responden, guru yang mengajar di sekolah swasta maupun sekolah negeri 19 responden, dosen musik diperguruan tinggi swasta ataupun negeri dengan status dosen tetap ataupun Tenaga Pengajar Luar Biasa atau TPLB 10 responden, musisi bebas yang aktif sebagai musisi band ataupun musisi orkestra 10 responden dan 1 responden belum bekerja karena masih menyelesaikan studi di Universitat fur musik und darstellende Kunz Grass austria.

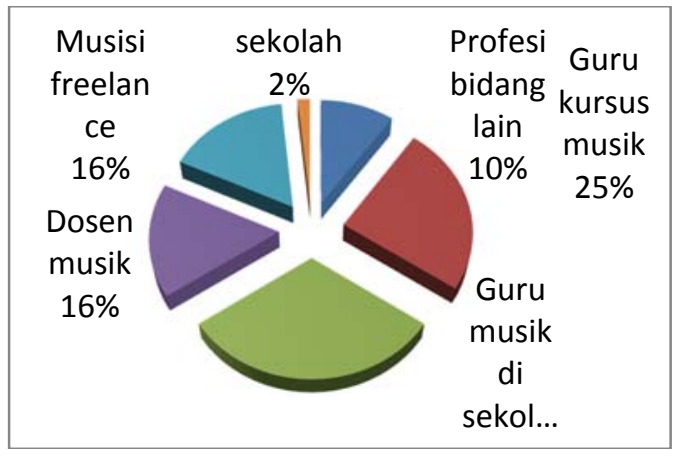

\section{Gambar 3.}

Profile Alumni

Jika di deskripsikan, profesi di luar bidang musik terdiri dari supervisor di usaha Onlineshop Margaria Group, Staf Kepala UKP4 (Unit Kerja Presiden bidang Pengawasan dan Pengendalian Pembangunan), pemilik Sound of English (N Workshop), karyawan di PT. Agung Concern, marketing di PT. Bona Mitra Property, karyawan di PT Rezim.

Profesi sebagai guru/ pengajar/ instruktur kursus musik tersebar di Tabela Harati Education, yayasan pendidikan musik fuga, Beethoven Music Course, Chandra Kusuma School, Kaizen Music School, Willy Sumantri Music School, Pattern Music Course, Purwacaraka Music School, Virtuoso Music Course, Pusat Pendidikan Musik Makaliwe, Yamaha music Indonesia dan Yayasan Musik Jakarta.

Profesi sebagai guru/ pengajar di sekolah mulai tingkat PAUD hingga SMA tersebar di Yogyakarta Community School, SMA Global Prestasi, Bekasi, SD cahaya bangsa (kinderstation), SD Al azhar 38 Bantul, SDN 6 Glagahsari, SMA Negeri 14 Surabaya, SMK Negeri 5 Yogyakarta, Bina Bangsa School Semarang \& SMM Yogyakarta, Dinas Sosial Panti Bina Sosial Remaja Sleman Yogyakarta, SMA Negeri 1 Rogojampi, SD Kindersatation Primary, SMA Muhammadiyah 2 Yogyakarta, Saint John's School, British Internastional School, hingga Sekolah Menengah Kejuruan Musik.

Alumni yang menjadi dosen bekerja di Jurusan Musik FSP ISI Yogyakarta, STKIP PGRI Banjarmasin, Univeritas Negri Makassar, Institut Seni Indonesia Denpasar, Universitas Universal dan Universitas Negeri Medan.

Adapun alumni yang bekerja sebagai musisi freelance sebagai pemain orkestra antara lain di Twilight Orchestra, Erwin Gutawa Orchestra. Sebagai musisi mereka juga sebagai pengajar privat, adapula yang membuka kursus musik. Selain itu ada juga yang membuka usaha bisnis bidang musik seperti jasa recording.

b. Riwayat Pekerjaan

Dari data kuesioner, para alumni sebagian besar memperoleh pekerjaan berdasarkan pertemanan atau koneksi. Ini bisa terlihat dari gambar di bawah ini :

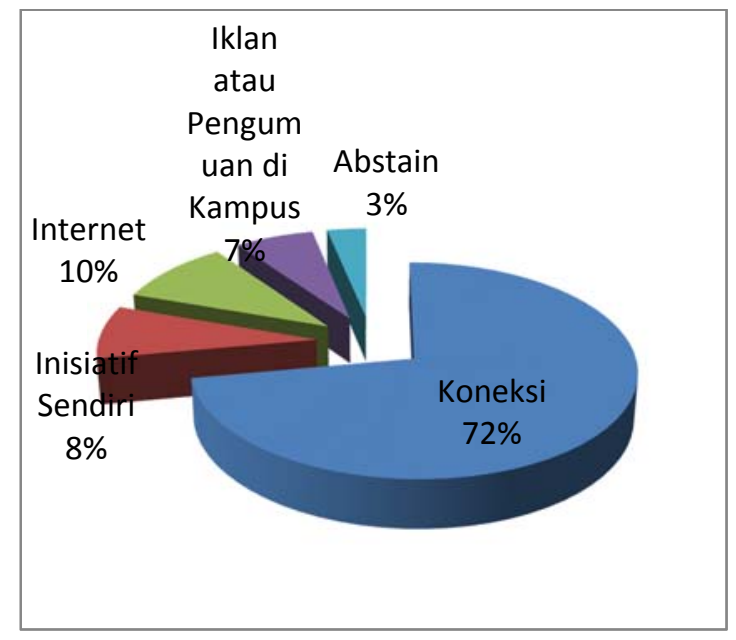

Gambar 4.

Cara memperoleh informasi Pekerjaan 
Sementara itu, kesesuaian harapan ketika mahasiswa menempuh studi di jurusan musik dengan realita profesi yang dijalani setelah selesai studi menunjukan telah sesuai harapan sebesar $49 \%$, sangat sesuai harapan sebesar 29\%, kurang sesuai harapan $26 \%$, tidak sesuai harapan 5\% dan abstain sebesar $3 \%$.

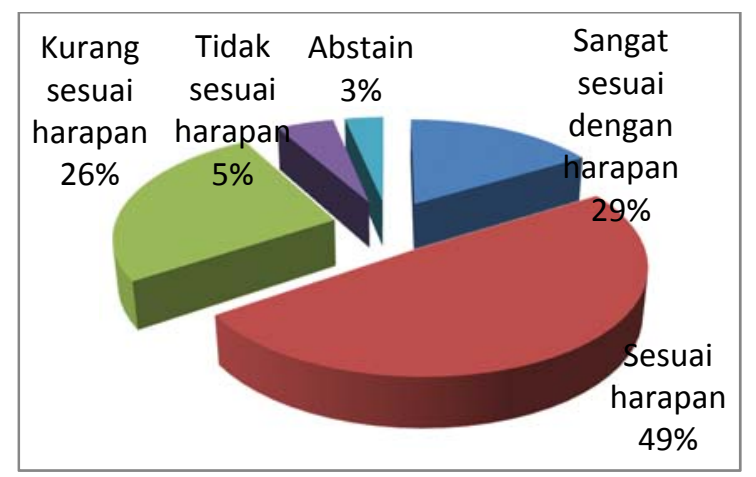

\section{Gambar 5.}

Kesesuaian antara pekerjaan dengan harapan ketika pertama kali belajar di Jurusan Musik

Jika melihat peluang pekerjaan dari masing-masing institusi dimana responden bekerja, bisa terlihat minat institusi terhadap lulusan dari jurusan musik adalah sangat tinggi sebesar $25 \%$, tinggi sebesar $51 \%$, rendah $16 \%$, sangat rendah $5 \%$ dan absatain $3 \%$.

c. Relevansi pendidikan dengan pekerjaan

Salah satu indikator perguruan tinggi yang baik adalah mampu mengantarkan anak didiknya memperoleh pekerjaan sesuai dengan keilmuan yang diperolehnya. Dari hasil temuan, sebanyak 51 responden menyatakan relevan, 6 responden menyatakan tidak, 2 responden menyatakan iya dan tidak dan 1 responden tidak menjawab atau abstain.

Relevansi antara pendidikan dengan pekerjan yang dijalani para alumni telah sangat baik. Meskipun demikian, banyak kritikan, masukan dan saran yang diberikan alumnus agar kurikulum di jurusan musik menjadi lebih baik lagi.

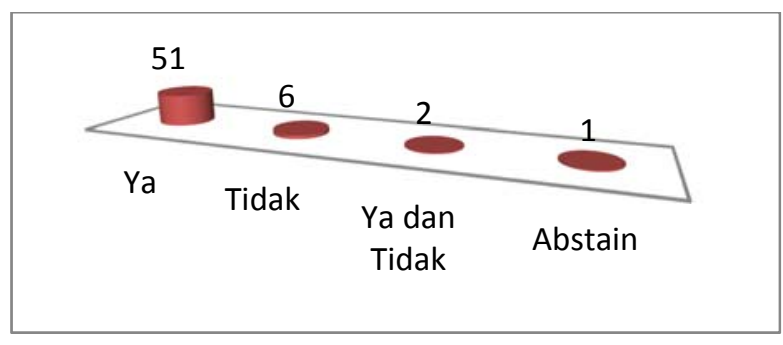

Gambar 7.

Relevansi pendidikan dengan pekerjaan

\section{Komentar dan saran para alumnus terhadap proses pendidikan}

Hal yang banyak disorot oleh para alumni dalam pengelolaan pendidikan di program studi S-1 seni musik dapat disimpulkan sebagai berikut:

a. Kompetensi dosen

Secara umum kompetensi dosen sudah cukup layak, baik dari sisi ketrampilan maupun intelektual. Setiap dosen diharapkan memiliki wawasan luas yang menguasai berbagai sudut pandang dalam melihat musik agar topik yang dibahas dalam perkuliahan bisa beragam dan bukan sekedar dosen yang pandai mengoreksi redaksional saja.

Komitmen waktu dalam perkuliahan harus lebih disiplin, tepat waktu dan yang penting lagi adalah jumlah tatap muka harus sesuai aturan. Dosen juga sebaiknya bisa mengatur jadwal mengajar dengan jadwal job (jangan sampai disebut dosen asongan) agar tidak merugikan mahasiswa.

Dosen sebaiknya mengetahui dan selalu mengikuti problematika musik di masyarakat (terkait isue, wacana dan persoalan yang muncul, dan bagaimana solusinya), Jadi tidak sekedar bicara musik secara tekstual atau teoritis belaka.

b. Pengembangan mata kuliah Untuk perbaikan dan pengembangan mata kuliah, para alumni memberikan saran 
yang dapat dijadikan intropeksi bagi program studi. Tidak untuk menjatuhkan namun justru membangun lebih maju. Misalnya, Dalam mata kuliah Metode Penelitian, mestinya harus ditumbuhkan pemikiran yang kritis lewat sebuah dialektika agar mahasiswa lebih memahami dan menyadari bahwa musik adalah bagian dari ilmu pengetahuan yang nantinya bermanfaat terhadap kualitas skripsi.

Untuk mata kuliah KKP atau kuliah kerja profesi mungkin perlu pengawasan dan pendampingan secara efektif karena berkaitan erat dengan pekerjaan ketika mahasiswa lulus kelak. Penguasaan kemampuan berbahasa inggris harus lebih ditingkatkan, karena setiap instansi pengguna lulusan hampir sebagian besar menuntut penguasaan berbahasa Inggris bagi calon karyawannya. Sering-sering, melibatkan mahasiswa dalam penelitian dosen. Hal ini sangat penting apabila program studi S-1 seni musik serius mengarahkan mahasiswanya ke profesi peneliti atau ilmuwan.

Mata kuliah Kapita Selekta harus dikaji ulang keberadaannya dan relevansinya bagi mahasiswa. Selain itu, sebaiknya program studi S-1 seni musik perlu menambahkan mata kuliah Kritik Musik. Mata Kuliah ini akan berguna sebagai pengembangan pemikiran dan wacana/ diskursus bagi mahasiswa lintas minat utama seperti penyajian, pengkajian, pendidikan, dan penciptaan.

Materi mata kuliah Pedagogi Didaktik Musik perlu dibahas lebih mendalam. Selain itu perlu kiranya mahasiswa musik khususnya minat utama musik pendidikan dibekali cara membuat administrasi guru misalnya RPP, Prota, dan Prosem.

c. Fasilitas belajar mengajar yang memadai

Ketersediaan sarana prasarana dalam menunjang kegiatan belajar mengajar harus- lah mutlak dilakukan. Pengadaan instrumen musik, kurangnya ruang perkuliahan, kelayakan ruang perkuliahan, pemeliharaan alat, teknisi instrumen musik hingga kebersihan fasilitas auditorium.

Pengadaan studio recording juga seharusnya mulai direncanakan, mengingat perkembangan teknologi musik yang begitu cepat harus diantipasi dengan bekal yang memadai terkait tren teknologi musik.

\section{d. Model pembelajaran di kelas}

Sederhana tetapi penting, akan lebih baik jika proses perkuliahan lebih banyak dilakukan dengan model diskusi aktif dan presentatif. Hal ini untuk memberikan pengalaman komunikasi aktif (bukan sekedar dosen ceramah atau mahasiswa membuat makalah dan dosen hanya menerima hasil tugas tanpa ada evaluasi yang tepat).

Kemampuan mempresentasikan pengetahuan musik secara lisan kepada orang lain sangatlah penting. Pengalaman keberhasilan mahasiswa dalam menjalin komunikasi secara aktif dan musik di bangku perkuliahan, secara tidak langsung akan mengembangkan kecerdasan inter dan intra personal mahasiswa.

Setiap tugas makalah yang diberikan hendaknya dibahas dan didiskusikan kembali agar mahasiswa mengetahui kelebihan dan kekurangan dari setiap tugas yang dikerjakan. Proses belajar tidak harus di dalam kelas, namun bisa juga melakukan praktik lapangan untuk mata kuliah tertentu.

\section{e. Kemampuan softskill mahasiswa}

Program studi S-1 seni musik diharapkan dapat membekali para mahasiswa dengan wawasan kepemimpinan, entrepreneurship yang memadai agar setiap alumni dapat mengembangkan potensinya secara individual dalam menghadapi tantangan global yang semakin kompleks. Dibutuhkan figur seniman yang bukan saja mahir dalam musical ability $\mathcal{E}$ competency 
namun juga musisi yang mampu menjadi pemimpin yang transformatif, mandiri, berprestasi dalam bidangnya, mampu membuka lapangan pekerjaan yang luas dalam percaturan bisnis musik, mampu bersaing di tengah arus situasi sosial, ekonomi dan politik yang dinamis. Sehingga diharapkan Sarjana Seni mampu merambah dunia yang lebih luas tidak cuma jadi sekedar "pengamen" dan menunggu "job".

\section{f. Membangun networking}

Sebaiknya program studi S-1 seni musik mulai menjalin kerja sama dengan lembaga pendidikan lain, baik dalam negeri maupun luar negeri, untuk mengadakan pertukaran mahasiswa dan/atau pengajar. Ini dapat memberikan wawasan, pengalaman, jaringan, dan informasi terkini bagi mahasiswa dan pengajar dalam mengembangkan karir di bidang musik.

Tidak lupa membangun jaringan yang lebih baik dengan institusi dan jasa publik pengguna lulusan ISI Yogyakarta khususnya alumni jurusan musik. Jaringan penting lainnya adalah membangun jaringan dengan alumni. Jika belum sanggup, ikatan jaringan tidak harus formal namun bisa dilakukan dengan menggunakan fasilitas media sosial seperti facebook, line atau whatsap agar ikatan kultural bisa tetap terjaga dan tetap merasa bertanggung jawab terhadap perkembangan Program studi S-1 seni musik.

ISI Yogyakarta harus selalu memutakhirkan pemetaan dinamika di luar agar memiliki tolok-ukur dalam menilai atau mematutkan dirinya sendiri. Saat ini, harus diakui bahwa pasar lah yang lebih menentukan. ISI Yogyakarta belum sebagai penentu pasar. Masih jauh dari kompetitif. Jadi, orientasinya harus ke luar, bukan ke dalam. Sesudah melakukan pemetaan, susunlah SWOT-nya hingga muncul platform konkret "siapa melakukan apa kapan, di mana, dan bagaimana".

\section{Tingkat Kepentingan Alumnus terhadap Model-model Proses Pembelajaran}

Berdasarkan pengalaman belajar di bangku kuliah, para alumni diminta pendapatnya mengenai pentingnya belajar di dalam kelas. Jawabannya adalah 23 responden menyatakan sangat penting, 33 responden menyatakan penting, 3 responden menganggap kurang penting dan 2 responden menyatakan tidak penting.

Mengenai pengalaman belajar di lab atau ruang praktik, 29 responden menyatakan sangat penting, 23 responden menyatakan penting, 5 responden mengatakan kurang penting dan 3 responden mengatakan tidak penting.

Untuk pengalaman belajar di masyarakat, mayoritas responden menyatakan sangat penting dengan 40 responden, diikuti dengan 17 responden yang menyatakan penting, 2 responden mengatakan kurang penting dan 2 responden lainnya mengatakan tidak penting.

Para alumni yang mengangap pengalaman magang di perusahaan atau instansi sangat penting sebanyak 31 respon-den, yang mengatakan penting sebanyak 25 responden, 4 responden mengatakan kurang penting dan 1 responden lainnya mengatakan tidak penting.

Mengenai pengalaman belajar dalam organisasi mahasiswa, 22 responden menyatakan sangat penting, 34 responden menyatakan penting, 4 responden mengatakan kurang penting dan 1 responden mengatakan tidak penting.

Sementara bagi pentingnya belajar dalam pergaulan kampus, 30 responden menyatakan sangat penting, 29 responden menyatakan penting dan 2 responden mengatakan tidak penting.

Indikator terakhir dari pengalaman pembelajaran terkait pengalaman belajar mandiri adalah 45 responden menyatakan sangat penting, 15 responden menyatakan 
penting dan 1 responden mengatakan tidak penting.

\section{Kompetensi dan daya saing Alumnus}

Guna menjaring data sejauh mana alumnus mampu bersaing dengan perguruan tinggi lain dapat disimpulkan bahwa 26 responden menjawab sangat mampu, 31 responden menyatakan mampu, 3 responden menjawab kurang mampu dan 1 responden abstain.

a. Lulusan Jurusan Musik yang diperlukan oleh lapangan pekerjaan

Sementara itu, kesiapan para alumni terkait lulusan jurusan musik yang diperlukan oleh lapangan pekerjaan adalah 29 responden menjawab pendidikan secara generik, 30 responden menyatakan spesifik, 1 responden berperilaku ambigu dengan menjawab keduanya dan 1 responden tidak menjawab.

- Generik (Umum) - Spesifik

- Generik dan spesifik $\square$ Abstain

2930

11

Gambar 16.

Lulusan Jurusan Musik yang diperlukan oleh lapangan pekerjaan.

b. Penguasaan Kompetensi Akademik Alumnus Saat Lulus

Berdasarkan indikator kompetensi dan daya saing telah dijabarkan dalam 12 item yaitu, 1) Pengetahuan umum, 2) Bahasa Inggris, 3) komputer, 4) Metodologi penelitian, 5) kerjasaman tim, 6) Keterampilan komunikasi lisan, 7) Keterampilan komunikasi tertulis, 8) Proses pemberdayaan masyarakat, 9) Pengetahuan teoritis spesifik fakultas/jurusan, 10) Pengetahuan praktis spesifik fakultas/ jurusan, 11) Manajemen pertunjukan/organisasi dan 12) Kepemimpinan/ leadership.

Namun dalam penjabaran diagramnya hanya 6 item yang ditampilkan dengan pertimbangan bahwa ke-6 item tersebut dirasa cukup mewakili kompetensi yang diperoleh selama duduk di bangku kuliah, antara lain: Metodologi penelitian. Untuk item ini 7 responden manyatakan sangat menguasai, 30 responden menyatakan menguasai, 22 reponden mengatakan kurang menguasai, 1 responden mengatakan tidak menguasai dan 1 responden lainnya abstain. Untuk kemampuan keterampilan komunikasi lisan, 16 responden menyatakan sangat menguasai, 34 responden menyatakan menguasai, 9 responden menjawab kurang menguasai, 1 responden menjawab tidak menguasai dan 1 responden lainnya abstain. Sementara kompetensi proses pemberdayaan masyarakat 9 res-ponden menyatakan sangat menguasai, 34 responden myatakan menguasai, 15 responden menjawab kurang mengasai, 2 responden tidak menguasai dan 1 lainnya abstain

Dalam perolehan pengetahuan teoritis spesifik fakultas/ jurusan musik, 14 respoden menyatakan sangat menguasai, 39 responden menyatakan menguasai, 7 responden menjawab kurang menguasai dan 1 lainnya abstain. Tentang manajemen pertunjukan musik, 10 responden menyatakan sangat menguasai, 36 responden menyatakan menguasai, 14 responden kurang menguasai dan 1 abstain. Sementara dalam hal penguasaan kepemimpinan atau leadership, 12 responden menyatakan sangat menguasai, 35 responden menyatakan menguasai, 13 responden menjawab kurang menguasai dan 1 responden abstain.

\section{Relevansi kurikulum dengan kebutuhan dunia kerja saat ini}

a. Secara umum

Mengingat penggunaan media teknologi dalam pendidikan sangat berperan 
besar dalam capaian pembelajaran dan peningkatan kualitas pembelajaran maka perlu penggunaan media teknologi dalam pengajaran di kelas. Keuntungan mengintegrasikan media teknologi dengan pembelajaran akan memudahkan saat memberikan contoh nyata dari hasil teori yang bersifat auditif atau materi bunyi dalam diskusi perkuliahan.

Pendalaman untuk mata kuliah aplikasi komputer sudah bagus secara teori namun akan lebih bagus lagi jika bekal teori tersebut dipraktikan langsung dalam kasus per kasus penulisan musik. Lebih jauh lagi, perlu dipikirkan mata kuliah aplikasi komputer tidak hanya berkutat di persoalan penulisan musik tapi juga merambah ke bidang teknik rekam suara, recording musik hingga pengolahan dalam konteks komposisi musik elektronik.

Pemilihan dosen dalam mengajar mata kuliah harus benar-benar sesuai kompetensi atau kebidangan. Kalaupun tidak, dosen yang bersangkutan wajib memiliki niat baik untuk meng upgrade keilmuannya agar konten perkuliahan bisa berguna kepada mahasiswa dan bukan menjadi kegiatan normatif presensi.

Untuk mata kuliah Akustik dan Organologi perlu adanya penambahan teori dan wawasan untuk pengetahuan materi dan bahan guna mengaplikasikannya pada ruang bangunan. Mungkin cukup menarik apabila mahasiswa program studi seni musik diajari ilmu 'perhitungan' dan 'pengukuran' suara/ akustik melalui angka atau ilmu pasti. Mata kuliah Akustik Organologi sebaiknya mulai memikirkan wawasan interdisiplin yang lebih jauh, seperti fisika bunyi, arsitektur bunyi dan akustik ekologi. Meskipun sebagai pengantar, mengenal konsep bunyi secara fisik sangat dibutuhkan sebelum memahami organologi musik.

Perlunya penambahan mata kuliah baru dalam sebaran kurikulum mengenai dasar-dasar kepemimpinan dan entrepreneurship yang diajarkan langsung dari para ahli yang berpengalaman dalam bidangnya agar cara pandang, sifat kepemimpinan dan jiwa wirausaha bisa tumbuh dan lebih berkembang di semua mahasiswa program studi seni musik. Di sinilah pentingnya ruang dialog antara seniman dengan pengajar yang bukan dari kalangan seniman, agar dapat lebih memahami bagaimana perspektif orang lain memandang persoalan seni atau musik.

Perlu adanya pelatihan keterampilan komunikasi lisan bagi mahasiswa, mengingat sebagian besar mahasiswa musik hanya terampil berkomunikasi dengan suara instrumen. Fokus akan capaian akhir setiap pembelajaran dan selalu inovatif dalam membuat konten perkuliahan, khususnya pada matakuliah Metode Kelas Musik Pendidikan, Metode Kelas Instrumen, dan Aransemen Musik Pendidikan, karena matakuliah tersebut sangatlah penting pengaplikasiannya dalam dunia pendidikan.

\section{b. Secara spesifik}

Sudah menjadi fenomena bahwa lulusan program studi S-1 seni musik pada akhirnya banyak yang menjadi musisi atau player. Sebuah pilihan profesi saat belajar musik namun bermakna tragis dengan emblem yang lekat dengan julukan sebagai 'tukang' atau 'kuli'. Seyogyanya wacana ini menjadi bahan evaluasi dan renungan kampus dalam merubah paradigma berpikir mahasiswa.

Perubahan pola pikir menjadi penting ketika mahasiswa harus menyadari bahwa mereka adalah 'seniman akademis', yang berbeda dengan istilahnya 'seniman padepokan/sanggar' (ini bukan dalam rangka menilai kekurangan maupun kelebihan masing-masing), namun tetap harus dibedakan ketika lulusan wajib menunjukkan bahwa ia adalah 'sarjana yang seniman', artinya pada saat tertentu ia harus 
mampu mempertangggung jawabkan track record-nya di masyarakat dengan mencerminkan karakter akademis.

Program studi S-1 seni musik adalah program studi musik pertama Indonesia. Namun, sekarang banyak bermunculan Program studi seni musik lainnya di berbagai daerah. Pilihannya tergantung pada kita semua apakah bersedia menjadi terdepan atau cukup menyejajarkan diri dengan Program studi seni musik lainnya.

Ke depan, yang lebih dibutuhkan oleh bangsa Indonesia adalah sumber daya manusia yang bukan sekadar kompetitif, tapi juga yang berkarakter atau "unik". Perlu kita sadari, bahwa untuk berkompetisi, kita masih perlu habis-habisan bekerja secara unbusiness as usual (non profit atau tidak mencari keuntungan) untuk bisa melampaui, katakanlah, Malaysia, Singapura, apalagi dengan negara Barat tempat tradisi musik klasik dipelajari di program studi seni musik. Oleh karena itu, guna mengimbanginya, diperlukan pula satu gedoran kuat yang bernama keunikan, yakni sebagai sosok unik Indonesia, yang sudah pasti kita dapatkan secara given "pemberian") dan tak banyak dipunyai bangsa lain, yaitu kekayaan budaya.

Apa relasi konkritnya dengan Jurusan Musik ISI Yogyakarta? Sebaran local genius (kearifan lokal) harus digali dan dielaborasikan dengan tradisi (musik) Barat sebagai instrumennya (ingat, instrumen/ alat bukanlah tujuan utama!). Benar bahwa kita perlu belajar kontrapung, solfegio, dan harmoni, tapi tak boleh berhenti di situ. Semuanya harus kita perlakukan sebagai sekadar alat untuk menggali dan mengolah apa yang sudah ada pada kita: budaya Indonesia. Dengan kata lain bagaimana musik timur dibaca menggunakan kaca mata ilmu Barat. Sebenarnya, banyak orang Barat yang sudah mengingatkan hal ini sekian puluh tahun lampau seperti yang telah dilakukan oleh musikolog dan komposer Walter Spies atau Collin McPhee.

Selain itu, keunikan juga bisa diraih dengan mendorong para mahasiswa sebagai pribadi-pribadi yang unik, bukan pengekor. Secara kongkrit perlu memberi banyak ruang bagi mahasiswa untuk lebih mandiri. Mereka perlu difasilitasi dan dipertemukan dengan seniman-seniman dari luar, magang di sanggar-sanggar seni, berkolaborasi dengan seniman yang sudah jadi, maupun residensi-residensi bahkan sampai ke luar negeri. Semuanya harus dalam skema "membangun keunikan", bukan "mencari duit" atau sekadar memenuhi tuntutan SKS perkuliahan.

\section{Penutup}

Kurikulum Jurusan Musik selama hampir 31 tahun ini mengalami bongkar pasang untuk mengikuti perkembangan keilmuan sesuai visi dan misi yang diembannya. Namun secara subtansi tetap mampu membawa para lulusannya bersaing di dunia kerja dan menjadi agen perubahan bagi perkembangan musik seni di Indonesia.

\section{Referensi}

Aróstegui, José Luis. 2011. A. Educating music teachers for the $21^{\text {st }}$ century, Rotterdam: Sense Publishers.

Cohen, Ruth N. 2004. Introducing Tracer Studies, guidelines for Implementing Tracer Studies in Early Childhood Programmes. Den Haag: Bernard van Leer Foundation.

Heidemann, Lutz. 2011. Only Successful Graduates Respond to Tracer Studies: A Myth? Results from the German Cooperation Project Tracer Studies. Bologna: Alma Laurea Working Papers.

Mendikbud. 2014. "Peraturan Menteri Pendidikan dan Kebudayaan Republik 
Indonesia No 49 Tahun 2014 tentang Standar Nasional Pendidikan Tinggi". Jakarta: Kementerian Pendidikan dan Kebudayaan.

Ross, Alistair. 2000. Curriculum: Construction and critique. London: Falmer Press 11 New Fetter Lane.

Schomburg, Harald. 2003. Handbook for Graduate Tracer Study. Moenchebergstrasse Kassel, Germany: Wissenschaftliches Zentrum für Berufs-und
Hochschulforschung, Universität Kassel.

Singarimbun, Masri dan Sofian Effendi. 1989. Metode Penelitian Survai, Jakarta: LP3ES.

Sugiyono. 2011. Metode Penelitian Kuantitatif, Kualitatif dan RED, Bandung: CV Alfabeta.

Wahono, Francis (2001). Kapitalisme Pendidikan antara Kompetisi dan Keadilan, Yogyakarta: Insist Press. 